\title{
INFERIORITY DAN PERILAKU BULLYING DIMEDIASI OLEH DORONGAN AGRESI PADA REMAJA SEKOLAH MENENGAH PERTAMA
}

\author{
Silvia Risa Istanti ${ }^{1}$, Muhammad Salis Yuniardi ${ }^{2}$ \\ ${ }^{1,2}$ Fakultas Psikologi Universitas Muhammadiyah malang \\ ${ }^{1}$ silviarisa18@gmail.com, ${ }^{2}$ salis_ardi@yahoo.com
}

\begin{abstract}
Abstrak. Bullying menempati posisi pertama dibandingkan kasus lainnya di dunia pendidikan. Penelitian ini bertujuan untuk menguji pengaruh inferiority terhadap perilaku bullying dengan dorongan agresi sebagai variabel mediator. Partisipan penelitian berjumlah 150 pelaku bullying yang merupakan siswa SMP. Hasil analisis mediasi menggunakan ordinary leeast square regression dengan macro SPSS model 4 dari hayes menunjukkan bahwa inferiority mempengaruhi perilaku bullying remaja melalui perantara dorongan agresi. Remaja yang memiliki perasaan rendah diri, lemah, tidak mampu melakukan suatu hal akan cenderung memiliki dorongan agresi untuk melakukan kekerasan berupa perilaku bullying kepada orang.
\end{abstract}

Kata Kunci: Dorongan Agresi, Perilaku Bullying, Inferiority

\begin{abstract}
Bullying has been reported as the most frequent cases in education. This study aimed to examine the effect of inferiority on bullying behavior with aggression as a mediator variable. Participants were 150 bullying actors which were junior high school students. The mediation analysis using ordinary leeast square regression through macro SPSS model 4 from hayes showed that inferiority influenced bullying behavior of teenagers mediated by aggression encouragement. It means that teenagers who have inferiority, weakness feeling, feel unable to do anything will have the aggression encouragement to make a violence by doing bullying actions to others.
\end{abstract}

Keywords: Aggression Encouragement, Bullying Behavior, Inferiority 
Berdasarkan data KPAI dari tahun 2011 hingga Agustus 2014 kasus bullying di Indonesia menduduki peringkat teratas pengaduan masyarakat yakni sebesar $25 \%$, dari total keseluruhan pengaduan di bidang pendidikan yakni 1.480 kasus, yang mengalahkan tawuran pelajar, diskriminasi pendidikan ataupun pungutan liar (KPAI, 2014). Berdasarkan daftar rekapitulasi Komisi Perlindungan Anak Indonesia (KPAI) pada tahun 2010 tercatat 139 kasus bullying terjadi di lingkungan sekolah, pada tahun 2012 tercatat 36 kasus, namun setalah mengalami penurunan kasus, pada tahun 2013 hingga tahun 2014 kasus bullying kembali meningkat hingga 98\% (KPAI, 2014).

Bullying merupakan sebuah keinginan untuk menyakiti dan membuat orang merasa terintimidasi dan menderita, perilaku ini dilakukan secara langsung, berulang dan dilakukan dengan senang hati tanpa perasaan bersalah oleh seseorang atau sekelompok orang yang lebih kuat dan tidak bertanggung jawab (Rigby, 2005; Veenstra et al., 2005). Salah satu faktor yang diduga memicu bullying adalah perasaan inferior dari pelaku. Perasaan inferior adalah perasaan rendah diri yang timbul karena perasaan kurang berharga atau kurang mampu dalam kehidupan sehari-hari (Suryabrata, 2010). Inferiority memiliki beberapa aspek diantaranya perasaan tidak aman (insecure), perasaan malu (skyness), dan menarik diri dari lingkungan (withdrawal) (Semium \& OFM, 2006).

Remaja yang inferior akan cenderung emosional dan perpotensi melakukan perilaku bullying dengan tujuan melindungi harga dirinya yang rapuh, menutupi kelemahannya, mendapatkan pengakuan, popularitas, mendapatkan banyak pengikut atau teman, serta ditakuti oleh teman-teman lainnya (Friedman \& Schustack, 2008; Semium \& OFM, 2006). Sebuah survei yang dilakukan kepada 200 siswa sekolah menengah di Vellore Distric menunjukkan bahwa siswa yang memiliki prestasi akademik rendah cenderung memiliki inferiority complex yang tinggi dan mereka akan cenderung melakukan bullying kepada rekan lainnya untuk menutupi kekurangan dirinya tersebut (Kalaivani, 2017).

Selain dipengaruhi oleh inferiority, munculnya perilaku bullying juga diduga dipengaruhi oleh dorongan agresi dalam diri remaja. Dorongan agresi merupakan dorongan seseorangan untuk meluapan emosi sebagai reaksi terhadap kegagalan individu yang ditampakkan dalam pengerusakan terhadap manusia atau benda dengan unsur kesengajaan yang diekspresikan dengan kata-kata (verbal) dan perilaku (non verbal) (Koeswara, 1988).

Beberapa orang menggunakan agresi untuk melindungi perasaan inferior yang berlebihan (inferiority complex) untuk melindungi harga diri mereka yang rapuh (Feist \& Feist, 2010). Beberapa individu mengganti perasaan inferior dengan bergerak menuju keadaan psikologis yang sehat dan gaya hidup yang bermanfaat bagi dirinya dan orang lain, namun ada pula yang menanggapi perasaan inferior dengan melakukan kompensasi secara berlebihan dan termotivasi untuk menaklukan diri dari orang lain atau menarik diri dari orang lain (Feist \& Feist, 2010). Bullying merupakan salah satu wujud dorongan agresi yang paling menggambarkan usaha individu untuk mengkompensasikan perasaan inferiornya dengan menyakiti, mengancam atau menakut-nakuti orang lain (Rigby, 2005).

Oleh karena itulah tujuan dari penelitian ini adalah untuk mengetahui pengaruh inferiority (perasaan inferioritas) terhadap munculnya perilaku bullying melalui dorongan agresi pada remaja khususnya remaja sekolah menengah pertama. 


\section{METODE}

Partisipan yang terlibat berjumlah 150 pelaku bullying yang merupakan siswa SMP usia 12-15 tahun. Separuh partisipan berjenis kelamin laki-laki (55\%) dan berusia 13 tahun $(43 \%)$.

Skala Inferiority terdiri dari 12 item dan terdiri tiga aspek yaitu perasaan tidak aman (insecure), perasaan malu-malu (shyness), dan penarikan diri dari lingkungan (Withdrawal). Skala Perilaku Bullying terdiri atas 8 item dan mengungkap tiga bentuk bullying yaitu fisik, verbal dan psikologis.

Skala Dorongan Agresi terdiri atas 16 item yang mencakup agresi fisik aktif langsung, fisik aktif tidak langsung, fisik pasif langsung, fisik pasif tidak langsung, verbal aktif langsung, verbal aktif tidak langsung, verbal pasif langsung, verbal pasif tidak langsung. Keseluruhan skala berupa skala Likert dengan 4 pilihan jawaban. Ketiga alat ukur ini juga memiliki koefisien reliabilitas $(\alpha)$ yang baik yakni: 0,83 untuk Skala Inferiority, 0,76 untuk Skala Perilaku Bullying, dan 0,86 untuk Skala Dorongan Agresi.

Uji mediasi menggunakan teknik analisis regresi Ordinary Least Square (OLS) Macro PROCESS yang dikembangkan oleh Hayes (2013). Seluruh analisis dilakukan dengan bantuan program SPSS for windows versi 22.

\section{HASIL}

Tidak ditemukan missing data dan semua data berdistribusi normal dengan nilai skewness dan kurtosis berada diantara taraf signifikansi $5 \%$ yakni $\pm 1,96$. Hasil uji asumsi linieritas menunjukkan adanya hubungan linier secara signifikan antara ketiga variabel. Berdasarkan perhitungan skor skala inferiority, perilaku bullying, dan dorongan agresi dapat diketahui sebagian besar partisipan memiliki inferiority, perilaku bullying, dan dorongan agresi dalam kategori sedang yakni dengan besar prosentase kategori inferiority 78\%, perilaku bullying 52\%, dan dorongan agresi 65\%. Kategorisasi ini mengacu pada norma kelompok yang menggunakan rata-rata dan standar deviasi.

Tabel 1.

Hasil Analisis Mediasi

\begin{tabular}{|c|c|c|c|c|}
\hline Variabel & $\mathrm{b}$ & $\mathrm{t}^{*}$ & $p^{* *}$ & $\mathrm{R}^{2}$ \\
\hline $\mathrm{X}^{*} \mathrm{Y}^{\mathrm{a}}$ & 0,13 & 2,22 & 0,028 & 0,032 \\
\hline $\mathrm{X} * \mathrm{M}^{\mathrm{b}}$ & 0,27 & 2,91 & 0,004 & 0,054 \\
\hline $\mathrm{M} * \mathrm{Y}^{\mathrm{c}}$ & 0,28 & 5,81 & 0,000 & 0,21 \\
\hline$X * Y^{d}$ & 0,06 & 1,03 & 0,304 & 0,032 \\
\hline
\end{tabular}

$* \mathrm{t}=1,66, * * p<0,05$

\section{Keterangan:}

$\mathrm{a}=$ Inferiority $*$ Perilaku Bullying (Total Effect)

$\mathrm{b}=$ Inferiority $*$ Dorongan Agresi

$\mathrm{c}=$ Dorongan Agresi $*$ Perilaku Bullying

$\mathrm{d}=$ Inferiority $*$ Perilaku Bullying (Direct Effect) 
Sebagaimana dapat dilihat pada tabel diatas, pertama, sumbangan inferiority terhadap dorongan agresi adalah signifikan $(b=0,27, t=2,91, p=0,004)$. Kedua, sumbangan dorongan agresi terhadap perilaku bullying adalah signifikan $(b=0,28, t=5,81, p=$ 0,000 ). Ketiga, pengaruh keseluruhan (total effect) inferiority terhadap perilaku bullying adalah signifian $(b=0,13, t=2,22, p=0,028)$. Keempat, pengaruh langsung (direct effect) inferiority terhadap perilaku bullying adalah tidak signifikan $(b=0,06, t=1,035$, $p=0,304$ ). Sementara itu, analisis pada pengaruh tidak langsung (indirect effect) dari inferiority (variabel bebas) terhadap perilaku bullying (variabel tergantung) menghasilkan effect $=0,0753$. Hal ini bisa dilihat pada Gambar 1 .

Dengan metode bootstrapping, uji mediasi yang dilakukan mendapatkan hasil biascorrected confidence interval berkisar antara 0,0137 sampai dengan 0,0281. Oleh karena angka 0 tidak tercakup dalam rentang confidence interval tersebut, maka dapat disimpulkan bahwa pengaruh tidak langsung (indirect effect) ini bersifat signifikan (tidak sama dengan 0). Dengan demikian pengaruh inferiority terhadap perilaku bullying diperantarai oleh dorongan agresi.

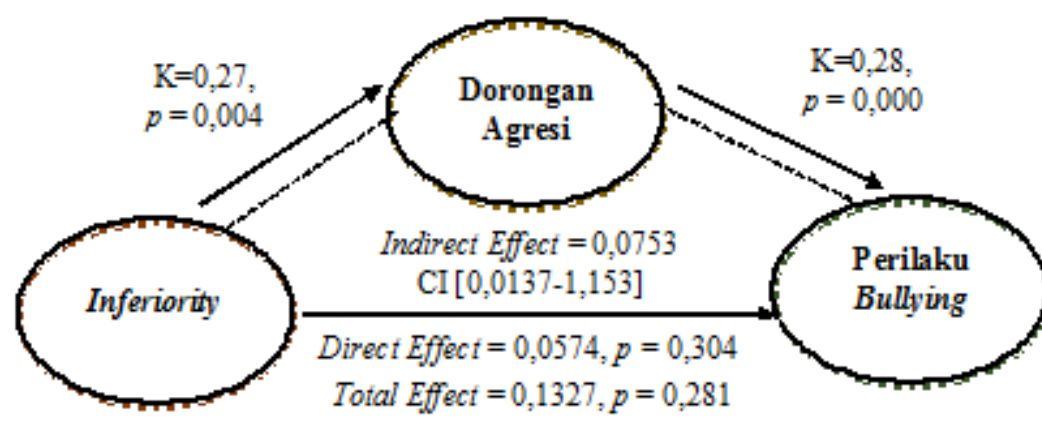

Gambar 1. Model Mediasi Inferiority dan Perilaku Bullying dengan Dorongan Agresi sebagai Mediator

\section{DISKUSI}

Penelitian ini hendak menguji apakah inferiority mempengaruhi perilaku bullying dimediasi oleh dorongan agresi dan hasilnya hipotesis terbukti. Hal ini mengindikasikan bahwa semakin tinggi inferiority siswa yang ditampakkan dengan perasaan rendah diri, merasa tak berdaya, dikucilkan dan lemah dibandingkan individu lainnya, maka semakin tingi pula dorongan agresi siswa yang ditampakkan dengan keinginan siswa untuk melakukan tindakan yang menyakiti, melukai teman lainnya, yang selanjutnya akan meningkatkan perilaku bullying pada siswa.

Hal ini sejalan dengan teori kepribadian yang menyatakan bahwa beberapa orang akan cenderung menggunakan agresi untuk melindungi perasaan inferior berlebihan (inferiority complex) untuk melindungi harga diri mereka yang rapuh (Feist \& Feist, 2010). Sebuah penelitian yang dilakukan kepada remaja-remaja yang akan masuk ke universitas membuktikan bahwa remaja yang merasakan inferiority complex akan cenderung pasif, memiliki keterampilan sosial yang buruk, kurang mampu 
mengendalikan emosi dan memunculkan perilaku anti sosial. Ketidakmampuan remaja dalam mengendalikan emosi yang didukung dengan keterampilan sosial yang buruk menyebabkan remaja tersebut memiliki dorongan agresi yang tinggi untuk melakukan kekerasan atau bullying kepada teman-teman sebayanya (Kenchappanavar, 2012).

Perlu dicatat bahwa dalam penelitian ini, pengaruh inferiority terhadap perilaku bullying dimediasi secara sebagian oleh dorongan agresi. Variabel inferiority masih memiliki pengaruh yang signifikan dengan perilaku bullying pada remaja ketika variabel dorongan agresi dikontrol atau ditiadakan. Sebaliknya, variabel dorongan agresi memiliki pengaruh signifikan terhadap perilaku bullying pada remaja meskipun pengaruhnya lebih kecil dibandingkan dengan variabel inferiority. Hasil penelitian menunjukkan sebagian besar responden memiliki tingkat inferioritas yang tinggi, namun mereka memiliki dorongan agresi yang relatif rendah, hasil lainnya juga menunjukkan bahwa perilaku bullying yang dilakukan oleh sebagian besar responden adalah bullying psikologis, yakni bullying yang dilakukan tanpa ada kontak fisik dengan korban, lebih tidak terlihat dan susah diamati. Hal inilah yang mungkin mempengaruhi kecilnya efek dorongan agresi dalam memediasi pengaruh inferiority terhadap perilaku bullying. Hal ini menandakan bahwa kondisi internal remaja yang bersifat rendah diri, merasa diasingkan, dikucilkan, berbeda dengan teman sebayanya, merasa lebih lemah dan berdaya tetap akan berdampak pada remaja untuk melakukan tindakan bullying, meskipun dorongan agresi dalam dirinya relatif rendah.

Terdapat beberapa hal yang menjadi keterbatasan dalam penelitian ini. Pertama, penelitian ini adalah penelitian dalam bentuk cross sectional study yang hanya memprediksi variabel $\mathrm{X}$ terhadap $\mathrm{Y}$, sehingga tidak bisa menjelaskan sebab akibat (causality). Kedua, penelitian ini tidak mengontrol faktor-faktor lain yang dapat mempengaruhi dorongan agresi dan perilaku bullying pada siswa seperti faktor perekonomian keluarga, konformitas, dukungan sosial keluarga dan lingkungan sekitar, stress dan depresi, dan pengalaman masa lalu, faktor tersebut mungkin sekali mempengaruhi dorongan agresi dan perilaku bullying pada siswa.

\section{SIMPULAN DAN IMPLIKASI}

Berdasarkan hasil penelitian ini, dapat disimpulkan bahwa terdapat pengaruh yang positif dan signifikan antara inferiority terhadap perilaku bullying melalui perantara dorongan agresi. Bagi penelitian selanjutnya diharapkan dapat mengembangkan penelitian mengenai perilaku bullying dengan menguji faktor-faktor lain yang mungkin terlibat ataupun mengembangkannya dalam uji kausalitas baik melalui penelitian longitudinal maupun experiment. 


\section{REFERENSI}

Feist, J., \& Feist, G. J. (2010). Teori kepribadian: Theories of personality. Jakarta: Salemba Humanika.

Friedman, H. S., \& Schustack, M. W. (2008). Kepribadian: Teori klasik dan riset modern. Jakarta: Erlangga.

Hayes, A. F. (2013). Introduction to mediation, moderation, and conditional process analysis: A regression-based approach. New York: The Guilford Press.

Kalaivani, G. (2017). "A study on inferiority complex of high school student in relation to their academic achievement" in vellore distric. Research Paper, 3(5), 93-96. Retrieved from https://issuu.com/internationaleducationalscientificr/docs/20._kalai_vani

Kenchappanavar, R. N. (2012). Relationship between Inferiority complex and Frustration in Adolescents. Journal of Humanities and Social Science, 2(2), 1-5.

Koeswara, E. (1988). Agresi manusia. Bandung: PT Eresco.

KPAI. (2014). KPAI: Kasus bullying dan pendidikan karakter.

Rigby, K. (2005). Bullyig in school and the mental health of children. Australian Journal of Guidance \& Counceling.

Semium, Y., \& OFM. (2006). Teori kepribadian \& terapi psikoanalitik Freud. Yogyakarta: Kanisius.

Suryabrata, S. (2010). Psikologi kepribadian. Jakarta: Raja Grafindo Prasada.

Veenstra, R., Lidenberg, S., Winter, A. ., Oldehinkel, A. ., Verhulst, F. ., \& Ormel, J. (2005). Bullying and victimizzation in elemntary schools: A comparison of bullies, victims, bully/victims, and univolved preadolescents. Developmental Psychology, $41(4), 672-682$. 